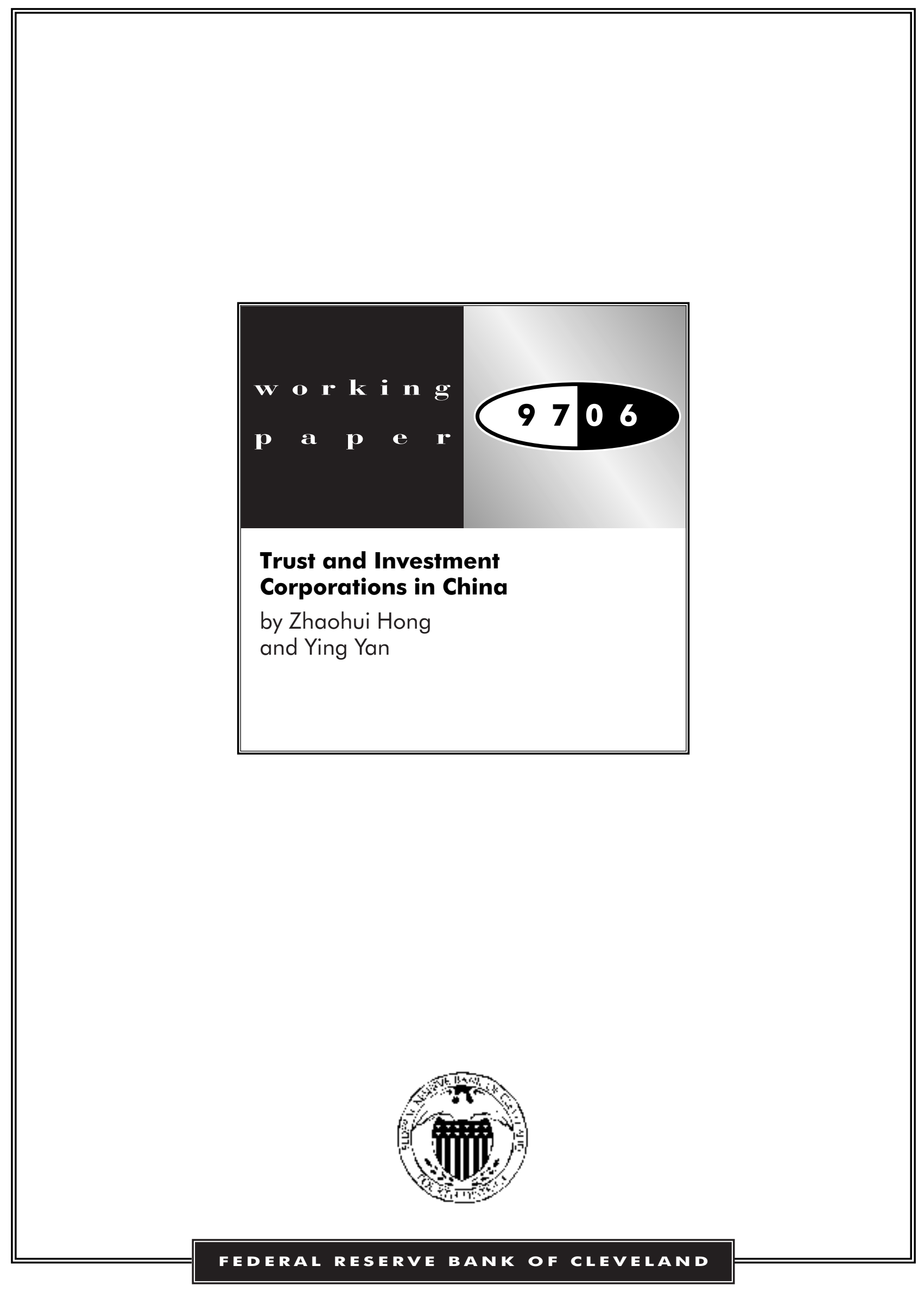




\title{
Trust and Investment Corporations in China
}

\author{
Zhaohui Hong, Ph.D. \\ Savannah State University of Georgia \\ Ying Yan, Ph.D. * \\ Federal Reserve Bank of Cleveland
}

\begin{abstract}
Trust and investment corporations (TICs) have played a very important role inChina's economic reform. However, this sector is now in a chaotic situation because it lacks proper regulation and clear distinction from other financial sectors. Substantial reform is imperative in order to sustain TICs' financial stability and avoid an adverse effect on the economy. This paper gives a detailed description of Chinese TICs' formation and expansion. After pointing out the problems and their sources, we suggest that TICs in China should resume the international standard trust services instead of conducting businesses that overlap with the banking and securities industries. Chinese settlors should be treated as shareholders instead of debtholders. To smooth out the process of transition, we propose an intermediate scheme that takes into account both the realities in China and the international trust operation standard. JEL classification Numbers: G2, L5, L84.
\end{abstract}

\footnotetext{
* Direct all coreespondence to: Ying Yan, Research Department, Federal Reserve Bank of Cleveland, P.O. Box 6387, Cleveland, OH 44101-1387
} 


\section{Introduction}

On January 13, 1997, one of China’s biggest trust and investment corporations, China Agribusiness Development Trust and Investment Corporation (CADTIC), was taken over by China Construction Bank. This highly visible event attracted a lot of international attention and was reported by The Wall Street Journal, Reuters, and other major newspapers worldwide. This is a remarkable symbol, as China's government is trying to stabilize its trust and investment industry by takeovers or leveraged buyouts. As central bank governor Dai Xianglong announced the same day: "As for some trust and investment companies that incurred serious financial risk, the central bank has taken them over, commercial banks have bought them out or new assets have been injected to shore up their finances......" (Reuters).

The takeover of CADTIC serves as a milestone as trust and investment corporations (TICs) in China enter a reform stage. In what ways the reform should be carried out, however, needs more serious debate on both the academic and the practical level. We feel that the special conditions of financial and economic transition need to be considered seriously, along with the international trust and investment business standards. How reform can properly combine both features is one of the important issues of this paper.

The remainder of this paper is organized as follows: Section II describes the formation and expansion of TICs in China. Section III examines the major differences between China's TICs and those of other countries. The origins of China's TIC crisis are analyzed in section IV, while the importance of reestablishing traditional TIC business is discussed in section V. The suggested measures for Chinese TICs during the transition period are proposed in section VI, and section VII summarizes and concludes the paper. 


\section{Formation and Expansion of TICs in China}

Before TICs were formed, most of the firms in China had only one resource for all their financial needs -- the state-owned banks. A lot of valuable projects were forgone due to the very restricted lending rules of state-owned banks. Firms had no alternative resources for their valuable projects if they could not obtain funding from state-owned banks.

As the economic reform in China went farther in the direction of market principles, the first Chinese TIC, China International Trust and Investment Corporation (CITIC), was formed under the direct supervision of the State Council in October 1979. The first president of CITIC, Mr. Rong Yiren, now vice president of China, successfully attracted a lot of uninvested cash. CITIC's total asset grew very fast. Then, more new TICs were established. They prospered because the interest rates offered by state-owned banks were simply too low to attract civil deposits.

Since TICs can offer higher interest rates to depositors, their assets expand at an astonishing speed. Furthermore, without much regulation or restriction, TICs offer almost all the services that state-owned banks can offer at a much lower cost. They play an important role in facilitating valuable private investment for firms that cannot obtain funding from state-owned banks. They can also carry on foreign-exchange business, while state-owned banks cannot. In fact, CADTIC was initially formed to create a legal entity that could accept agricultural loans from the World Bank because the China Agricultural Bank, the only official bank for agribusiness in China, could not conduct foreign-exchange business in 1980s. Because TICs met the immediate financial needs of an economy that was shifting away from central planning towards a market scheme, they soon developed into an important industry in China. 
However, the similar financial services provided by TICs pose an immediate danger to state-owned banks, which are still under tight central-bank control and unable to compete with TICs. In order to ease the problem, the State Council gave state-owned banks permission to conduct trust business on July 10, 1980. Observing the lucrative opportunities in this area, many banks began to operate their own trust business as a subdivision. By 1995, out of only 391 TICs in existence, 186 (almost half) were TICs operated by banks. (People's Daily, January 4, 1997).

After more than a decade of reorganization and adjustment, TICs in China can be categorized into five different types. The first type is under direct central government control (e.g., CITIC, CADTIC) and benefits substantially from strong ties with the central government. Their branch offices and subsidiaries are numerous, some in foreign countries. CITIC, the largest TIC in China, has 37 subsidiary companies domestically and internationally with total assets of 166.7 billion yuan. CITIC also has its own commercial bank, which has 17 branch offices and is ranked sixth among Chinese commercial banks in total assets. Profits from its bank subsidiaries are CITIC's main income source and compose 73\% of CITIC's total profit (People's Daily, April 8, 1996). CADTIC, however, had more than 50 branch offices in Zhejiang Province alone by 1994. Its total assets reached 26.9 billion yuan, with 260 million yuan net profit in 1994. Its international business brought in more than $\$ 64$ million profits in U.S. dollars. (People's Daily, February 27, 1995). TICs in the second category are sponsored by local government (e.g., Shanghai International TIC and Beijing Real Estate TIC). Those in the third category are supported by firms in other industries, such as insurance or real estate. TICs in the fourth category are founded by foreign banks or joint ventures. The fifth category consist of TICs that are subsidiary to commercial banks (e.g., the TIC of the China Industrial and Business Bank). However, due to the mandatory legal separation of banks and the trust business, many of the 
major commercial banks (e.g., China Industrial and Business Bank, China Agricultural Bank, China Bank, and China Construction Bank) had completed the separation process by November 1995. Thus, the number of TICs in the fifth category dropped from 186 to 38 by the end of 1995 (People's Daily, January 4, 1997).

\section{Major Differences between China's TICs and Those of Other Countries}

The trust business is very popular in western countries. Its primary purpose is to facilitate the transfer and management of properties. Settlors (or grantors), the original owners of the trust assets, have a fiduciary relationship with the trustee, that is, a relationship of faith or trust. Any person with the power of control, management, or disposition over the funds of the trust is a fiduciary. Fiduciary duties and powers, as well as the rights of the beneficiaries, are specified primarily by the provisions of the will or trust agreement. This agreement, often referred to as "the governing instrument," controls the administration of the trust account unless its terms violate applicable law or are inconsistent with public policy. The fiduciary duties specified in trust agreements vary widely, but their most common features are as follows (for a more detailed account of these duties, see BAI, 1976):

a) The duty of undivided loyalty

The trustee must administer the property exclusively in the best interests of the beneficiaries. The trust institution must not allow itself to be placed in a position in which its own interests conflict with those of the beneficiaries. The fiduciary may not profit in any way from his advantageous position. Only the beneficiaries, who sometimes include the settlor himself, should enjoy the benefits derived from the trust property. 
If a fiduciary is involved in activities against "parties-in-interest," it will be considered a breach of a trust by law.

b) The duty to take possession and maintain control of assets

The terms of a trust instrument almost always specify that the trustee is to have exclusive management of the trust property. Occasionally, the trust agreement even serves as a receipt for the original assets transferred to the trustee. Having obtained possession of trust property, the trustee's duty is to protect and manage it. If the trust property is subject to tax liability, a mortgage, or other encumbrance, the required payments should be made to prevent the loss of the property through a tax or foreclosure sale.

One of advantage of a trust is the successive management of trust property, independent of a trustee's situation. If something happens to the trustee (e.g., resignation, bankruptcy, or even death), the court has the right to appoint a new trustee to continue the management of trust property (Zhou, 1996).

c) The duty to separate and earmark trust and estate property

A fiduciary has a duty to keep trust and estate property segregated from property owned by the fiduciary in his own right. If trust or estate funds are mingled with the trustee's own funds contrary to the terms of the governing instrument, the trustee is guilty of a breach of trust.

d) The duty to make the trust property produce income

The usual objectives of a personal trust are to confer immediate and continuous financial benefits on beneficiaries in the form of income, while simultaneously conserving the capital. A trustee, therefore, is generally under a duty to put the trust property into a form that regularly produces economic benefits such as interest, rents, or dividends that can be paid over to the current beneficiaries. 
For some trusts, such as an employee benefit trust or a charitable trust, the most important function is to produce a satisfactory "total return," rather than current income. Total return includes changes in capital value as well as dividend and interest income.

e) The duty to remit income to the beneficiary

The trustee has a duty to distribute the "net income" to the beneficiaries at reasonable intervals (on a quarterly basis, if the governing instrument does not specify the frequency). Net income is defined as gross income less proper deductions, allowances, and reserves.

f) The duty to exercise care and skill

A fiduciary is required only to meet the standard of "the prudent man rule." This means that the duty of the trustee is to exercise such care and skill as a man of prudence, discretion, and intelligence would use in dealing with his own property. If an individual fiduciary actually has greater skill or more facilities than the ordinary man of prudence, he may be held to a higher standard (for example, a corporate fiduciary often represents himself to the public as an expert).

However, the trustee has only limited liability for the trust property, as long as there is no proof of negligence. None of the trustee's personal assets can be seized as compensation for the lost trust property. This limited liability rule protects the trustee's interest and helps him to provide optimal service for investors and beneficiaries (Meagher and Gummou, 1986). If negligence is found, the trustee is subject to a surcharge by the court.

g) The duty to provide information to beneficiaries

A fiduciary is obliged to give complete and accurate information to beneficiaries concerning the administration of the account. A trust remainderman is likewise entitled to receive this information. 
h) The compensation for trustee

The fee charged by that trustee usually composes a percentage of the market value of the principal assets, or a percentage of gross income, or a combination of both. Using only a percentage of market value of the principal assets as the fee standard allows compensation to fluctuate as investment performance relates to the market. Using only a percentage of income as the fee keeps compensation rather stable, but does not reward or penalize the trustee's investment decisions. A fee structure encompassing both income and corpus fees can provide stability in falling markets and some measure of reward as the market rises.

Furthermore, the fiduciary relationship includes not only that of trustee and beneficiary, but also that of principal and agent. The distinction between the responsibilities of an agent and a trustee is explained as follows:

"An agent acts for and on behalf of his principal and is subject to his control; a trustee as such is not subject to the control of his beneficiary, although he is under duty to deal with the trust property for the latter's benefit in accordance with the terms of the trust. The agent owes a duty of obedience to his principal; a trustee is under duty to conform to the terms of the trust." (BAI, 1976)

Agency is a special kind of trust service most frequently observed in investment management accounts. The agent's management of assets for a principal may be on a discretionary or an advisory basis. In a discretionary account, the agent can execute transactions without consulting the principal. In an advisory account, the agent must obtain the principal's approval before executing any transaction. Agency services are very popular in western countries. 
In China, however, the trust originated as a financial resource to supplement banks when the country's economy shifted away from central planning. Thus, China's TICs have none of the features described above. On the contrary, the settlors in China enjoy debtholders' rights, which are identical to those of commercial bank depositors. Their features are as follows:

a) The trustee pays settlors a fixed rate of interest, which usually is much higher than the rate paid by state-owned banks.

b) The trustee is the residual claimant of the trust property. This means that he enjoys all the benefit derived from the trust property after paying the promised interest rate to settlor.

c) When there is a serious loss in the trust property due to mismanagement or economic recession, the central bank or commercial banks come in to take over the trust business and pay off the settlor.

Therefore, we can see that TICs in China basically perform the role of commercial banks but with much less regulation and restriction. This will inevitably create financial chaos.

Furthermore, the trust industry is unregulated in most western countries. This means that entry to or exit from the industry is determined by market forces without much government intervention. Therefore, TICs place no charter value on their business identities.

Counterexamples are regulated industries such as banks, utility companies, etc. To open in the U.S., for example, a new bank must be approved by banking regulatory authorities. It therefore has a charter value on its identity. Whether or not TICs in China carry charter value has not yet be determined.

The regulations of governing TICs in China also need to be clarified. There seems to be some kind of regulation since some authorities must approve the opening of a new TIC. However, it is unclear who has the authority. The Central bank, local government, and some 
bureaus all seem to have authority to approve TICs' operating licenses. This, of course, creates a chaotic situation for trust businesses and substantially reduces the charter value of existing TICs.

\section{The Origins of China's TIC Crisis}

According to the Temporary Regulation on the Management of Trust and Investment Corporations, issued by the China Central Bank in 1986, TICs are allowed to do business in the following categories:

a. trust business specified by settlors or testators

b. general trust business requested by settlors or testators without any special specifications

c. leasing business associated with financing

d. agency services related to trust asset management, including collection, conservation, and issuing securities

e. securing and issuing currency debt

f. other services approved by the China Central Bank.

Notice that only the first two categories specified above are considered part of traditional trust business internationally; the other four categories are not (Zhou, 1996). The typical loan services that TICs provide should include fixed-asset loans, inventory loans, short-term loans, loans on collateral, etc. However, many Chinese TICs engage in high-risk activities they are forbidden to do, including investing heavily in real estate and/or stock speculations. When the 
stock market or real estate market goes down, huge losses appear on their TIC balance sheets. This creates a lot of financial instability.

In addition to providing services that banks and securities companies provide, TICs also invest in various other industries. For example, CADTIC used to own businesses in international shipping and handling, traveling, electricity generation, manufacture of automobile parts, and food production. Such TICs, therefore, are "financial giants." In essence, they are not TICs any more.

The composition of TIC clients in China is also quite different from that of other countries. Elsewhere, personal trusts, such as living trusts, investment trusts, property trusts, retirement trusts, heritage trusts, annuity trusts, will trusts, testamentary trusts, net gift trusts, etc., compose most of the trust business. In China, however, the major trust business is the corporate trust. This is because Chinese TICs have put their business emphasis on industry sectors but ignored providing traditional personal trust services for individuals. This phenomenon is also related to some aspect of Chinese ideology, such as devaluing individualism or believing that a curse attaches to dealing with death or will. As a result, the personal trust businesses is almost entirely ignored.

The capital structure of TICs in China, however, resembles that of a bank rather than a trust company. Their asset includes both trust property and the trustee's equity. In particular, both the profit and the risk belong to the trustee instead of the settlors. Settlors receive a fixed rate of return as depositors (Zhou, 1997). Further, TICs cannot get loans from banks, according to China's central banking law and commercial banking law. Either they are not allowed to take personal funding as liabilities. This create a very peculiar situation: As a result, many TICs borrow inappropriately, incurring triangle debt, lending out borrowed money, and performing 
fictitious transitions, etc. (Huang, 1995). In order to compete with banks to raise money, TICs must offer settlors interest rate as high as $20 \%$, while the loan interest rate they charge for their funding projects is up to $40 \%$. This causes a lot of financial chaos, since TICs' high interest charges directly increase the bankruptcy probability of their debtors.

Finally, changing economic and financial environments also have serious effects. TICs were formed to supplement the inefficient and inflexible state-owned banking system in the 1980s. However, as economic reform has progressed, the commercial banks have undergone substantial reforms. TICs are gradually losing their traditional advantages of high interest rates and flexible services. Now banks can provide better service and engage in businesses that were closed to them before. For example, commercial banks can now conduct business in foreign exchange, which was previously the exclusive domain of TICs. The banking system reform definitely enhances the competition in TICs. In addition, China's securities industry has grown very fast, providing competing services that have caused TIC industry to decline. Numerous TICs now are in financial crisis. Their funding is deficient. Their equity capital ratios are lower than $8 \%$, which is the minimum level required to avoid financial warnings. Many TICs use their shortterm deposits to fund long-term debt, which inevitably creates liquidity problems. TICs have now reached the stage where substantial reform is unavoidable to maintain their financial stability. As banking and the securities industry have come to play their own roles in the economy, it is now time for TICs to conduct their own trust business instead of seizing business from banks and securities companies.

\section{The Importance of Reestablishing a Traditional TIC Business in China}


The trust industry has unique features that banking and the securities industry cannot provide. One of these functions is managing and protecting trust properties, generation after generation without interruption. The trustee has full authority to manage trust property but does no share the benefits derived or bear the risk. The trustee secures the trust property to the beneficiaries and provides professional services for them. No other industry could perform these functions. The features of the traditional trust business guarantee the fundamental demand for this industry. What TICs in China need to do is to clarify the mixed financial services they provide and concentrate on standard trust business. Doing so will enable them to regain financial stability by attracting clients and distinguishing themselves from banks and securities companies.

In addition, TICs should provide not only private but also public trust services, such as charitable, and employee benefit trusts. When property owners want to donate assets to a beneficiary who is either too young or who lacks the skills to manage the assets properly, TICs are the natural agents to turn to. More commonly, people would like to increase the value of their assets or property but they lack the ability to manage it successfully. TICs are designed to provide them with this expertise without sharing their risks and profits. Thus, traditional trust services are very attractive and have a very good market.

In fact, the potential demand for traditional trust business in China is huge, especially for its unique protective feature. Due to the legal independence of trust property, neither the debtors of the settlor nor the debtors of the beneficiary can claim trust assets that are under a trustee's management. This means that even in the event of the bankruptcy of the settlor or his beneficiary, the trust asset is unseizable. Trust law states that the beneficiary of the trust rather than the settlor's debtors has priority in recovering ownership of the trust assets (Zhou, 1996). This protective feature is especially attractive to Chinese, because of the political upheavals and 
dramatic policy changes they have gone through. Now the economy is growing so fast that many people become millionaires within a few years. They all search desperately for a legal way to protect their private assets or property, worrying that they might be confiscated overnight due to some dramatic change in the political environment. This is especially true for those who gained their fortune through illegal or improper activities. TICs' protective trust services could not only satisfy their personal need but also channel their money back efficiently for reinvestment to stimulate the economy.

China's high rate of economic growth surely provides a large market for trust business. Statistics show that the amount of deposits reached 3,000 billion yuan at the end of 1996 (Yan, 1997). Now more and more people are interested in better investment opportunities than just earning the low interest rate available from their banks. The average financial assets per person increased from 40 yuan in 1978 to 2,400 yuan in 1995, while total financial assets owned increased from 39.8 billion yuan in 1978 to 3,000 billion yuan in 1995. In other words, within 20 years, financial assets per person have increased 60 fold (Financial Times, June 5, 1995). This growth lays a very solid foundation for a thriving trust business.

Furthermore, the ongoing reorganization of state-owned firms also provides many chances for trust business growth. Because of changes in governmental function, local and central governments do not have the right to manage money left beyond the initial planning. Therefore, the amount of state-owned assets increased from 20 billion yuan in 1950 to 3,500 billion yuan in 1995. Of these assets, about 1,000 billion yuan are used inefficiently and should be transferred. Assets that are not in use at all amount to 300 billion yuan (Financial Times, June 17, 1995). Therefore, state-owned firms need an external agent to manage those assets. This is the best time to develop corporate trust business. In addition, with an improved shareholder 
system for state-owned enterprises, state-owned shares also need an agent to represent their interests. This offers a good opportunity for developing an intangible trust business.

In 1993, the State Council issued a new law mandating the separation of financial business among insurance companies, securities, trusts, and banks (Zhou, 1997). Although this regulation reduces some service categories that TICs used to provide, it also help TICs resume their traditional trust services. By early 1997, the separation of commercial banks from their sponsored TICs was almost complete. As a result, more than 100 billion yuan of assets have been successfully transferred from banks to TICs. This substantially increases TICs' business opportunities and market share (People's Daily, January 4, 1997). This law provided a good preparation for TICs to totally recover their traditional trust business with their independent identity and assets.

From our current perspective, we can clearly see that TICs in China have great futures, in spite of the current problems. However, we need to ensure that TICs transformation will be as smooth as possible. Some new trust services should be introduced to satisfy Chinese customers' special needs. In addition, an intermediate scheme is necessary for the transition period.

\section{Proposed Measures for China's TICs in the Transition Period}

First, TIC regulations need to be clarified and unified. A trust, by its legal nature, is characterized as a fully independent agent. Thus, it requires an independent authority and examiner (Zhou, 1996). We suggest setting up a unified authority to impose some transitory regulations on the trust business in order to guarantee its successful transformation. However, the trust business should ultimately be allowed to operate according to market forces, without much regulatory intervention. 
Privatizing TICs' ownership will improve their operating efficiency. Publicly-owned TICs are controlled by market forces. If they are not efficient, they can not survive the competition. However, most TICs in China are still state owned. CADTIC, for instance, used to be owned by the Ministry of Agriculture. Since its dissolution in 1996, CADTIC's numerous branches, which are located in different areas, have been owned by local governments. Those state-owned TICs do no have a balanced decision-making process; thus, they cannot prevent the controlling party from being inefficient or abusive (Zhou, 1997).

Many Chinese TICs are too small to diversify their financial risks adequately. Their asset quality is low and their services are not professional. Their financial vulnerability seriously affects the trust industry's reputation. If the industry were competitive, those TICs would already be out of business. However, in the transition period, we need to set up a minimum asset requirement to induce mergers and acquisitions to solve this problem.

In the case of big TICs that are financially insolvent, if mergers and acquisitions are necessary, a conservatorship is needed to smooth the transfer of assets. For example, in 1995, when the TIC of the China Bank became insolvent due to excess debt and mismanagement, it was put into conservatorship by Guangdong Development Bank, which officially purchased all its shares one year later and sustains all its debt. This merger enables Guangdong Development Bank to expand its trust business from the local level to the international level. Meanwhile, this transaction pays off the immense debts of China Bank. Thus, it protects the interests of both the debtholders and shareholders in China Bank. In addition, all the former employees of China Bank, following the principle that workers should move with assets, are employed by the Guangdong Development Bank (People’s Daily, November 7, 1996). 
With regard to trust services, TICs should make more effort to do business in personal trusts, including deposit, investment, estate, retirement, heritage, annuity, will, testamentary, net gift, and donation trusts. In China, which has one-third of the world's population, the market for trusts is huge. However, because most Chinese do not have much knowledge about trusts, a lot of marketing, advertising, and education efforts are needed to stimulate the enormous potential demand. Before long, we should be able to observe thriving business in personal trusts, since that is where consumer demand will be hugest.

For corporate trusts, more emphasis should be put on intangible trusts, in addition to tangible trusts. Three new kinds of intangible trust services should be introduced to Chinese firms. The first one, the "voting right trust," focuses on representing shareholders interests by voting on various occasions. In a well-developed country, most firms have boards of directors involved in major managerial decisions. There is a certain percentage of board members who represent shareholders' interests. However, this is not the case in China, especially for some TICs. Since many companies have numerous shareholders, widely scattered across the country, it is impossible to have a general shareholder meeting when it is imperative to make a decision. In addition, many shareholders have little knowledge about the management and operation of their firms anyway. Therefore, shareholders' interests are inadequately represented in the managerial decision process. Thus, it is necessary for shareholders to turn over their voting rights to TICs, which can represent their interests in case of a vote and also provide a professional monitoring function for the management and operation.

The second kind of service is the "guaranteed debenture trust," which can offer additional security for company debentures. This kind of trust is designed to improve investors' confidence 
in firms that want to issue bonds and debentures but need a reliable institution to guarantee their debt value. TICs, by nature, could provide this kind of service effectively and reliably.

The third kind of service is the "financial distress turnover trust," in which the trustee specializes in managing a firm under financial distress. A lot of special knowledge is needed when a manager must operate a firm that is close to financial insolvency. Most managers know only how to manage a healthy firm and lack the knowledge to deal with a troubled one. The financial distress turnover trust could provide the specialized knowledge needed to assist the incumbent manager in turning around a bad financial situation. This service should be very valuable, especially for the large number of state-owned firms that are currently in financial trouble.

Public trust services, like charitable trusts and social security trusts, also need to be developed in China, which is undergoing substantial reform of social security and health insurance. The new system incorporates both government assistance and individual payment for the funding. The administrators who control the money are not usually professionals in managing financial assets, but TICs should be suitable for managing those funds. This will not only improve the funds efficiency of usage but also maintain their independent status to avoid mismanagement. For the charitable trust service, many nonprofit organizations have been formed to accept public donations, especially those from overseas (e.g., the fund for the victims of June 4, etc.) The assets of the Hoping Project, the charitable fund for improving educational opportunities for needy Chinese teenagers in rural areas, already exceed 100 million yuan. Those funds definitely need to be managed professionally before they are to be used properly. By ensuring that those funds are well managed and correctly used, TICs will be able to collect more donations, since people will feel secure that the money they contribute will be handled properly. 
As to services that TICs provide but which overlap with other sectors: Some of them should continue into the transition period in order to smooth out the transformation process. China should allow TICs to keep their securities business temporarily and with appropriate restrictions. Although incorporating the securities business into trusts will increase the risk of the trust business, the common services they provide, like investment banking or financial consulting, will help stabilized their organizations before new service demands are successfully identified in the general public. We suggest that TICs should be temporarily allowed to operate as investment banks, whose primary role is that of middleman between investors and fund raisers through a securities market (Wang and Tang, 1995). The general services that an investment bank provides are listed in the appendix.

Regarding the role of settlor, the change from debtholder to shareholder is very dramatic for most Chinese who are usually very risk-averse. A new middle position is proposed here to resolve the problem of stabilizing the trust business during the transformation. We propose that, during the transition period, settlors' principal should be guaranteed, although standard shareholders could loss all their money in economic downturns. However, trust investors should profit from a trustee's good investment, instead of earning a fixed interest rate. On the other hand, the trustee's incentives need to be aligned with settlor although he is not the residual claimant of the trust assets. One way to achieve this is to give the trustee a certain percentage of the profit he makes as a bonus. The trustee's basic pay for management services should be lower than formerly, so that he has an incentive to work harder and do a good job for settlor. Government assistance might still be needed in this scheme when the trust business turns insolvent. However, the only debt that needs to be cleared up, in the event of default, is the 
principals. This scheme should be able to serve as an intermediate stage between current TICs and future, well-developed TICs.

We have a lot of confidence in the future of TICs, in spite of their current problems. The process of transformation is always difficult and it takes time and effort. We are sure that before long the Chinese people will realize how important trust services are to their daily life.

\section{Summary and Conclusion}

TICs play such an important role in China's economy that their current crisis cannot be ignored. We identify the source of the crisis as TICs' duplication of services already provided by banks and securities companies. This is related to another problem: that settlor in China now play the role of debtholders instead of shareholders. We point out all the major differences between China's TICs and those in other countries.

We recommend that, in order to clear up the chaotic situation and sustain their financial stability, TICs should recover all their normal trust services and give up the financial business they have seized from the banking and securities industry. We also propose various measures for transforming the current TICs, including introducing new trust services and an intermediate scheme to smooth out the transition process. We hope our paper will serve to encourage more research in this area. 


\title{
APPENDIX
}

\author{
General Services of an Investment Bank
}

1. Provide the securities investment trust in which investors' asset value could be increased reliably through good securities investment.

2. Supply financing for firms that need long-term investment.

3. Issue, secure, and underwrite new bonds and stocks.

4. Provide consulting services for individuals.

5. Provide consulting services for companies, including mergers, acquisition, capital adjustment, and policies.

6. Provide brokerage services by buying and selling state treasury bonds, government bonds, certificates of deposit, stocks, etc. 


\section{REFERENCES}

Baker, P.V., \& Langan P. St. J.(1982). Snell's Principles of Equity. London: Sweet \& Maxwell, 28th ed.

Bank Administration Institute, (1975). Trust Operation Manual. Park Ridge, Illinois.

Bank Administration Institute, (1976). Trust Account Administration, Park Ridge, Illinois.

Fang, J.L. (1994). The Theory and Practice of Trust Law (xintuofa zhi lilun yu shiwu). Taipei: yuedan chubanshe gufen youxiangongsi.

Federal Financial Institutions Examination Council. (1995). Trust Assets of Financial Institutions. Washington, D. C.

Huang, L.G. (1995). The Separated Management of Finance and Outlet of Trust and Investment Corporations (Jinrong fengye jingying yu xintuo gongsi de chulu). Paper presented at the Symposium of Guangzhou Finance and Enterprise Reform, Guangzhou, China.

Meagher, R. P., \& Gummow, W. M. C. (1986). Jacobs' Law of Trusts. Sydney: Butterworths, 5th ed.

Miller, M. H. (1996). Alternative Strategies for Corporate Governance. In Xu Dianqing and Wen Guanzhong (eds.) Reform of State Owned Enterprises in China. Beijing: Zhongguo jingjichubanshe.

Nan, Y. (1997). Analysis of Personal Financial Assets in China (Geren jinrong zichan fenxi). Dadi Monthly, 64, 31-32.

Parker, D. B. \& Mellows, A. R. (1975). The Modern Law of Trusts. London: Sweet \& Maxwell, 3rd ed.

Wan, F.L. (1994). The Practice of Banking Credit and Trust Investment (Yinhang xindai yu xintuo touzi shiwu), Beijing: zhongguo shangye chubanshe.

Wang, C. \& Tang, D.J. (1995). Management and Operation of the Investment Banks in the World (Geguo touzi yinghang guanli yu yunzuo). Guiyang: Guizhou renming chubanshe.

Zhou, X.M. (1996). Where to Go--the Identification and Future Direction of China's Trust under a Policy of Separation between Different Financial Businesses (Zhongguo xintuoye: hequ hecong). Jingji daokan (Journal of Economics), February, 13-20.

Zhou, X.M. (1997). Studies on the Comparative Law of Trust System (Xintuo zhidu bijiaofa yanjiu), Beijing: faluu chubanshe. 